\title{
Think
}

http://journals.cambridge.org/THI

Think

Philosophy for everyone

Additional services for Think:

Email alerts: $\underline{\text { Click here }}$

Subscriptions: Click here

Commercial reprints: Click here

Terms of use : $\underline{\text { Click here }}$

\section{OPEN-MINDEDNESS IN SCIENCE EDUCATION}

Guilherme Brambatti Guzzo and Guilherme Duarte Garcia

Think / Volume 14 / Issue 41 / September 2015, pp 99 - 103

DOI: 10.1017/S1477175615000184, Published online: 14 September 2015

Link to this article: http://journals.cambridge.org/

abstract S1477175615000184

How to cite this article:

Guilherme Brambatti Guzzo and Guilherme Duarte Garcia (2015).

OPEN-MINDEDNESS IN SCIENCE EDUCATION. Think, 14, pp 99-103 doi:10.1017/S1477175615000184

Request Permissions : $\underline{\text { Click here }}$ 


\section{OPEN-MINDEDNESS IN SCIENCE EDUCATION Guilherme Brambatti Guzzo and Guilherme Duarte Garcia}

Critical thinking is widely regarded as one of the main objectives of education in general terms, and also of science education. The idea of thinking critically, that is, to evaluate adequately and eventually embrace a certain claim only if there are good reasons for it, however, seems to contradict some popular conceptions about other educational ideal: open-mindedness. The purpose of this essay is to discuss how critical thinking and open-mindedness are not exclusionary ideals, and how those ideas are important for science education.

The development of thinking skills and dispositions is widely regarded as one of the main objectives of general education. Authors like the philosopher Matthew Lipman maintained that education should develop people capable of thinking clearly, giving reasons to support their points of view, and asking for reasons before embracing new ideas. Ideally, students should value good reasons when deciding if a certain argument is well supported or not. In reality, however, this is restricted to a small fraction of those in the education community.

Science education, along with philosophy classes, may present the best scenario for the development of thinking capacities. The work of scientists demands some of the thinking skills considered to be essential also for students, even if they will not pursue a scientific career after they graduate. Thinking critically, that is, demanding evidence before reaching a conclusion about a certain claim, is in the core of any scientific endeavor, and should play a 
similar role in daily activities. Crucially, the thinking process should be evaluative across the board, not only in academia - scientists who do not think critically outside academia simply have double standards, and this is not the characteristic of an honest intellect.

How can someone know if the last vitamin supplement that is advertised on TV really prevents health problems? And if your neighbor argues that he saw on the internet that vaccinating kids can cause diseases and make them prone to certain medical conditions, such as autism? How about the man who says he can communicate with dead people on the TV show? There is only one safe way to find out if something is probably true or not: asking for good reasons that support the affirmation. Even accepting that it is difficult to assess certain claims, especially if we lack technical knowledge of the aspects involved in the discussion, evidence is what one needs before embracing or rejecting a certain idea.

So, thinking critically may be seen, by some people, as something that appears to be against other of the aims of education: open-mindedness. In fact, if we consider some of the popular definitions for the term 'open-mindedness', they appear to be incompatible with good thinking. Stephen Law $^{1}$ presents a fictional story that may help discussing a popular idea about being open-minded. In the story, a character named Dave firmly believes that dogs are spies from the planet Venus, and the alien dogs are planning to invade Earth and take over our planet. His friends, Mary and Pete, try to dissuade him from what they consider a foolish idea, presenting arguments against Dave's point of view. Mary and Pete talk about the absence of evidence to sustain Dave's claims: there are no communication tools that dogs from Earth could use to talk to their Venusian fellows, dogs are physically not capable to fly an aircraft, Venus has a very hot atmosphere, and no living thing could stand it, and so on. Each argument presented by Mary and Pete is objected by Dave, who presents new ideas to respond to these objections as the discussion goes on. It 
should be noted that Dave does not present what one can consider good evidence in response to the criticism of his friends: according to him, it is not possible to detect the transmitters the dogs possess, Venusian dogs can live there because they avoid the surface of the planet, they have special spacecrafts that can be controlled with their paws, and so on. Even so, would Dave be right if he accused his friends of being close-minded, considering that Mary and Pete seemed to reject even to listen carefully to his arguments? If the term 'open-minded' is understood as 'willing to listen to, think about or accept different ideas' as it is presented in the sixth edition of the 'Oxford Advanced Learning Dictionary of Current English', possibly the most used English dictionary by people who do not have this language as their mother tongue, the answer is yes, Dave is probably right in saying that his friends are close-minded (assuming that this term is the opposite of 'open-minded').

The definition mentioned above is a very popular one, and put into action by people who promote pseudoscience and other themes that are sold to the general public as if they were scientific. Some of the defenders of pseudoscientific claims argue that subjects like intelligent-design (creationism) should be taught in schools as an alternative to evolutionary science. 'Present the alternative', some of them say, and 'let the students decide which idea to accept'. If not, the argument goes, students will be introduced to a narrow view of science - and of the world in general terms - a view that may discourage the development of open-mindedness. It does not matter, for them, if intelligent design lacks solid evidence, and if its ideas are best defended in the same way Dave protects his Venusian-dog hypothesis against a critical scrutiny. By the same rationale, how many other alternative views (to which there is not evidence whatsoever) should schools teach?

'Open-mindedness means that one does not accept a certain conclusion as dogma, but only tentatively and in proportion to the available evidence. By that standard, the 
scientific theory of evolution is what an open mind should accept, since it is overwhelmingly supported by the available empirical evidence', writes philosopher Massimo Pigliucci. ${ }^{2}$ Being open-minded, then, means being willing to accept new ideas, provided that good reasons exist in support of them. Being an open-minded person, thus, is thinking critically, basing claims on good reasons and good evidence. Open-mindedness cannot be summarized in an exercise of rhetoric, like the one Dave practiced when defending his claim, a situation in which anything can be regarded as a valid argument as well as you show enough eloquence to persuade your interlocutor. Such an exercise is futile, but is often used by more educated people who wish to defend some sort of double standard in the thinking process, as mentioned above.

In science education (and in education, in general), being an open-minded individual means accepting the authority or arguments instead of the argument of an authority. When faced with a better argument, i.e., an argument that is based on better evidence than the one a person accepted before, open-mindedness should drive this individual to reconsider his position, and eventually change his mind. If there is not any good reason to accept a different idea (e.g. 'dogs are invaders from Venus'), an open-minded person should reject it. That's why Dave's friends cannot be labeled as close-minded people - and neither can those who oppose the idea of teaching intelligent design as an alternative to evolutionary science. When considering evidence that regards the evolution of the living things, for example, the current consensus of scientific community is that animals, plants, and any other biological beings evolved by a natural process, commonly referred to as evolution. To deny this is to be close-minded.

Science works with evidence. Science education should follow the same pattern - indeed, thinking itself should follow such pattern. What is taught in science classes, in schools and universities, should reflect the best knowledge science has achieved until the present moment. It does not 
suggest, obviously, that science can offer definitive answers about how the world works. What it indicates is that some ideas are better than others, and the difference between a bad and a good idea is the evidence that supports the latter. Science education, in order to foster openmindedness, should reinforce the importance of reasons in scientific endeavors, as well as in other aspects of students' lives.

Guilherme Brambatti Guzzo is a Assistant Professor in the department of Biological Sciences at the University of Caxias do Sul, Brazil.guibguzzo@gmail.com

Guilherme Duarte Garcia is a PhD student in the department of Linguistics at McGill University, Canada.

\section{Notes}

${ }^{1}$ Stephen Law, Believing Bullshit (New York: Prometheus Books, 2011), 73-74.

${ }^{2}$ Massimo Pigliucci, Nonsense on stilts: how to tell science from bunk (Chicago: The University of Chicago Press, 2010), 170. 